Filol. Linguíst. Port., São Paulo, v. 18, n. 2, p. 319-355, ago./dez. 2016 http:/ /dx.doi.org/10.11606/issn.2176-9419.v18i2p319-355

\title{
A oração subordinada adjetiva na produção de sentidos no texto: a perspectiva dos livros didáticos de língua portuguesa do Ensino Médio
}

\author{
The adjectival subordinate clause in the production of \\ meaning in the text: the prospect of Portuguese textbooks in \\ high school
}

\author{
Aliana Lopes Câmara* \\ Instituto Federal de São Paulo, Matão, São Paulo, Brasil
}

\begin{abstract}
Resumo: Este trabalho estuda o modo como livros didáticos de Língua Portuguesa do Ensino Médio, aprovados pelo Programa Nacional do Livro Didático-2015, propõem o ensino da oração subordinada adjetiva. Vários pesquisadores (Bagno, 2011; Neves, 2011; Travaglia, 2009, 2011) abordam a questão do ensino de gramática, problematizando o ensino mecanicista e tradicional de identificação e classificação de unidades linguísticas (morfológicas e sintáticas). Esses autores defendem a articulação da gramática com o ensino das habilidades leitora e escritora, de modo que os recursos linguísticos sejam estudados na mobilização de efeitos de sentido na construção textual. A escolha do corpus, portanto, foi determinada pela proposta de ensino de gramática explicitamente declarada nos manuais para o professor (parte anexa ao livro didático), segundo a qual os recursos linguísticos são subsidiários ao ensino da leitura e da escrita. Parte-se, inicialmente, da comparação entre a proposta dos manuais quanto ao ensino da gramática e o que se efetivou no livro do aluno, mais especificamente em relação às propostas para o ensino da oração subordinada adjetiva. A seguir, a partir da descrição funcional da oração subordinada adjetiva (Câmara, 2015), que tem como
\end{abstract}

Professora de Língua Portuguesa e Espanhola do Instituto Federal de Educação, Ciência e Tecnologia - IFSP, Matão, São Paulo, Brasil, e pesquisadora do Grupo de Pesquisa em Gramática Funcional (GPGF) de São José do Rio Preto. E-mail: aliana.precioso@gmail. com. 
base a Gramática Discursivo-Funcional (Hengeveld e Mackenzie, 2008), verificase como alguns aspectos descritivos podem ser subsidiários ao ensino da oração subordinada adjetiva, visando ao desenvolvimento das habilidades de leitura e escrita. A justificativa para a escolha desse suporte teórico está no fato de que a gramática está estruturada de modo hierárquico e descendente em níveis e camadas de análise linguística, sendo que as unidades pragmáticas determinam as unidades semânticas, que, por sua vez, determinam as unidades morfossintáticas, que, por sua vez, determinam as unidades fonológicas. Os dados demonstram que ainda permanece, nas propostas de ensino da oração subordinada adjetiva, em livros didáticos de Ensino Médio, um ensino de gramática que enfoca principalmente o domínio de nomenclatura, de metalinguagem e de regras da gramática normativa. Não se realiza uma reflexão dos recursos linguísticos, a partir de textos autênticos, com o objetivo se entender como os efeitos de sentido são produzidos. Por outro lado, esses materiais apresentam uma visão diferente da tradicional ao considerar aspectos pragmáticos na concepção da oração adjetiva explicativa.

Palavras-chave: Ensino de gramática. Leitura e produção textual. Análise de livro didático. Oração subordinada adjetiva. Gramática Discursivo-Funcional.

\begin{abstract}
This paper studies how Portuguese textbooks of high school, approved by the Programa Nacional do Livro Didatico-2015, approach the teaching of adjectival subordinate clause. Several researchers (Bagno, 2011; Neves, 2011; Travaglia, 2009 , 2011) address the issue of grammar teaching, questioning the mechanistic and traditional teaching of identification and classification of linguistic units (morphological and syntactic). These authors argue the articulation of grammar with the teaching of reader and writer skills, so that linguistic resources are studied in mobilizing effects of meaning in the textual construction. The choice of textbooks corpus, therefore, was determined by the grammar teaching proposal explicitly stated in the manuals for the teacher (part attached to the textbook), under which linguistic resources are subsidiary to the reading and writing teaching. First we compare the proposal of manuals on the teaching of grammar and what was accomplished in the book of the student, more specifically on the proposals for the teaching of adjectival subordinate clause. Then, from the study on the functional description of the adjectival subordinate clause (Câmara, 2015), which is based on Functional Discourse Grammar (Hengeveld e Mackenzie, 2008), we studied how some descriptive aspects can be subsidiary for the teaching of the adjective clause, aiming at the development of reading and writing skills. The reason for the choice of this theoretical support is the fact that grammar is hierarchically
\end{abstract}

Câmara, AL. A oração subordinada adjetiva na produção de sentidos no texto... 
structured in levels and layers of linguistic analysis, and the pragmatic units determine the semantic units, which in turn determine the morphosyntactic units which, in turn, determine the phonological units. The data show that remains, in the educational proposals of the relative clause in high school textbooks, a grammar teaching that focuses primarily in the nomenclature, metalanguage and in the normative grammar rules. There isn't many reflection of the linguistic resource from authentic texts to understand how the effects of sense are produced. On the other hand, these materials have a different view of traditional teaching, because some of them consider pragmatic aspects in the non-restrictive relative clause concept.

Keywords: Grammar teaching. Reading and textual production. Textbook analysis. Adjectival subordinate clause. Functional Discourse Grammar.

\section{PALAVRAS INICIAIS}

Verifica-se atualmente uma grande preocupação de diversos estudiosos (Bagno, 2007, 2011; Neves, 1993, 2011; Travaglia, 2009, 2011) com o ensino de gramática na escola. Esses pesquisadores visam a modificar a postura tradicional de ensino de gramática, cujas bases estão arraigadas à prática de identificação e classificação das unidades linguísticas. Tal preocupação resultou na elaboração de uma gramática pedagógica (Bagno, 2011), cuja proposta é repensar o ensino dos conteúdos gramaticais a partir dos resultados de pesquisas descritivas sobre o português brasileiro. Em sua gramática pedagógica, o autor defende que se considerem, no ensino da oração subordinada adjetiva, as diferentes estratégias de relativização do português brasileiro no ensino de gramática. Uma de suas sugestões, por exemplo, diz respeito ao uso do pronome cujo, praticamente inexistente no português, principalmente em contextos de menor formalidade. $\mathrm{O}$ autor propõe que se parta de uma pesquisa que contraste o uso idealizado de cujo pela gramática tradicional com o uso real, para que o aluno desenvolva a habilidade de monitorar sua produção linguística de acordo com o grau de formalidade do discurso.

Em consonância com as propostas desses autores, realiza-se aqui uma interface entre a descrição e o ensino, visando a trazer contribuições de estudos descritivos para o ensino de gramática. Essa interface, por um 
lado, contribui para as discussões sobre o ensino de gramática e, por outro lado, motiva o surgimento de novas questões para a pesquisa. Além disso, na medida em que se buscam novas alternativas para o ensino tradicional de gramática, pretende-se contribuir para a diminuição da descrença dos professores com relação ao ensino de gramática, situação relatada em Neves $(1993,1999)$.

O tema em foco aqui já foi investigado por outros estudiosos, a partir de distintas perspectivas teóricas. Do ponto de vista formalista, Corrêa (1998) investiga a aquisição da oração adjetiva padrão na escola, chegando à conclusão de que o aprendizado da adjetiva preposicionada ocorre apenas nos anos finais da escolaridade básica, momento em que o aluno é exposto às diversas estratégias de relativização existentes, o que lhe permite escolher entre uma ou outra alternativa. Entretanto, ser exposto a essa diversidade não significa que o aluno desenvolve um uso produtivo da adjetiva padrão preposicionada. Ao contrário, os dados analisados pela autora mostram que dificilmente isso ocorre e que normalmente os alunos irão optar por estruturas equivalentes. Da mesma forma, Kenedy (2007), ao estudar a aquisição das relativas preposicionadas por crianças que têm como língua materna o francês, o espanhol, o inglês e o servo-croata, chega à conclusão de que esse tipo de relativa não pertence à gramática natural do falante dessas línguas e que só será adquirida pelos falantes por meio de um processo de escolarização.

Desde uma abordagem cognitivo-funcional, Bispo (2007) também realiza uma interface entre a descrição e o ensino. A partir dos resultados descritivos sobre a adjetiva cortadora, o autor tece algumas propostas para o ensino de gramática. Dentre elas, propõe que o professor atente às expectativas e necessidades dos alunos. Isso significa que o professor não deve trabalhar exclusivamente com a relativa padrão, mas também com as relativas não-padrão (copiadora e cortadora), pois são essas que estão presentes na fala dos alunos. $\mathrm{O}$ autor apresenta como alternativa para $\mathrm{o}$ ensino da oração relativa as atividades de reescrita de textos, momento em que se pode trabalhar com a comparação entre as diferentes estratégias de relativização, levando os alunos a desenvolverem a habilidade de adaptar sua produção linguística às diferentes situações comunicativas.

Bispo e Silva (2011), por seu turno, em um estudo sobre as adjetivas não-padrão da língua portuguesa, defendem a necessidade de se ir além do ensino tradicional de gramática que considera os casos de variedade 
linguística como desvio de norma. Além disso, os autores defendem que o ensino da oração subordinada adjetiva seja contextualizado, promovendose a reflexão sobre as diferenças e/ou semelhanças semânticas e estruturais entre elas.

Como se verifica, os estudos sobre o ensino da oração subordinada adjetiva focalizam as estratégias não-padrão, com o objetivo de mudar a postura de ensino de gramática que se limita à variedade padrão da língua. A proposta deste estudo, por outro lado, é investigar o ensino da adjetiva restritiva e da explicativa, investigando como se dá a relação entre leitura, gramática e escrita nos livros didáticos, e apresentando algumas contribuições para o ensino da oração adjetiva, a partir de uma interface com resultados descritivos (Câmara, 2015). Para isso, parte-se de algumas propostas sobre o ensino de gramática (Bagno, 2007, 2011; Neves, 1993, 1999, 2011; Travaglia, 2009, 2011).

Deve-se observar que, apesar de vários fatores influenciarem a postura tradicional de ensino de gramática, como as coerções editoriais, as expectativas dos pais, a formação dos professores, etc., tais fatores não são considerados neste estudo, pois se pretende analisar exclusivamente as propostas de ensino de gramática presentes nos livros didáticos (doravante LD), que, como material orientador do trabalho docente, também influenciam (ou determinam, muitas vezes) o ensino de gramática.

De acordo com Travaglia (2011, p. 54), deve-se desenvolver a competência comunicativa do aluno, definida como a capacidade "de usar cada vez um maior número de recursos da língua de maneira adequada à produção do(s) efeito(s) de sentido desejado(s) em situações específicas de interação comunicativa". Desse modo, o estudo dos recursos gramaticais deve subordinar-se ao desenvolvimento das habilidades de leitura e escrita. Partindo desse pressuposto, Pezatti e Câmara (2014) e Câmara e AbreuTardelli (2014) investigaram as propostas de ensino da oração subordinada adjetiva no Ensino Fundamental, chegando à conclusão de que esse tópico gramatical tem sido predominantemente trabalhado de modo tradicional. A despeito da diversidade de gêneros textuais presentes nos LD, inclusive nas seções sobre reflexão linguística, o texto é usado essencialmente como pretexto para atividades mecânicas de identificação e classificação das unidades linguísticas. Pretende-se averiguar aqui se esse mesmo quadro se configura no tocante ao tratamento dado à oração subordinada adjetiva nos LD de Ensino Médio. 
$\mathrm{O}$ artigo se encontra dividido da seguinte forma: inicialmente, discutimos alguns pressupostos teóricos norteadores do ensino de gramática na atualidade (Travaglia, 2009, 2011; Neves, 2011). Em seguida, apresentamos brevemente o arcabouço teórico da Gramática DiscursivoFuncional (Hengeveld e Mackenzie, 2008), dentro do qual destacamos as características descritivas da oração subordinada adjetiva. Na terceira seção, apresentamos a metodologia e o corpus desta pesquisa e, na quarta seção, analisamos como a oração subordinada adjetiva é apresentada nos LD e como são elaboradas as atividades referentes ao tema, buscando-se verificar se de fato se relaciona o ensino de gramática ao de leitura e de escrita. Na última seção, apresentamos algumas considerações finais.

\section{FUNDAMENTAÇÃO TEÓRICA}

\subsection{Algumas considerações sobre o ensino de gramática}

Travaglia (2009, 2011) e Neves (2011) denunciam e criticam uma tradição de ensino de gramática que focaliza principalmente o ensino prescritivo das unidades linguísticas. Segundo esses autores, há uma grande preocupação quanto ao ensino de gramática a partir de atividades de identificação e classificação das unidades linguísticas, além de, muitas vezes, ser possível questionar-se a qualidade das descrições apresentadas. Para Neves (2011, p. 116), a visão de gramática que se apresenta no ensino é a de um "mapa taxonômico de categorias", desvinculadas do seu funcionamento na interação, ou seja, independentes das funções e sentidos que desempenham no discurso.

O quadro apontado por Travaglia $(2009,2011)$ e Neves (2011) justifica a nossa proposta de interface com o ensino, uma vez que, segundo os autores, as descobertas dos estudos linguísticos devem alimentar as discussões sobre ensino de gramática, em prol de uma mudança na postura tradicional que esse tema vem recebendo na escola. O ponto de vista aqui adotado, em consonância com o proposto pelos autores, é que o objetivo principal da escola não é ensinar teoria(s) linguística(s), mas sim tornar os alunos competentes no uso da língua nas mais diferentes situações, e no manejo adequado das modalidades falada e escrita. Ao propor uma interface entre a descrição funcional e o ensino, este estudo respalda-se na 
preocupação atual do ensino em se considerar a língua em uso em diversas situações interacionais.

O propósito do ensino de gramática deve visar à educação linguística, definida por Travaglia (2011, p. 25) como o estudo dos recursos linguísticos a partir dos sentidos veiculados no texto. Por meio de uma educação linguística, é possível desenvolver a competência comunicativa dos alunos, que é o objetivo principal das aulas de língua materna. Desenvolver a competência comunicativa significa permitir ao aluno usar os recursos linguísticos de modo apropriado a cada situação de interação, de acordo com os objetivos que pretende atingir (Travaglia, 2009, 2011). O que se propõe aqui, seguindo Travaglia (2011), é o trabalho com a descrição e a reflexão sobre os fatos linguísticos, para que o aluno desenvolva sua criatividade no uso adequado e eficaz de seu instrumento de interação social, que é a sua língua materna. Segundo Câmara e Abreu-Tardelli (2014), é importante trabalhar-se a gramática no contexto de interação, no texto, com base nos pressupostos do Falante sobre as informações pragmáticas do Ouvinte. Essa posição está de acordo com os PCN (Brasil, 1998), que propõem que o trabalho com a gramática seja ampliado por meio de uma atividade reflexiva, utilizando uma terminologia simples que permita chegar a resultados diferentes dos obtidos pela gramática tradicional. Segundo Travaglia (2011), devem-se entender os recursos linguísticos como mecanismos para produzir/entender determinados efeitos de sentido, com a intenção de atingir determinadas intenções comunicativas.

Percebe-se, dessa forma, que nossa proposta difere essencialmente do modo como a gramática tem sido tradicionalmente trabalhada na escola, em que se focaliza principalmente o ensino de nomenclaturas e de classificações. Além disso, distancia-se também de uma perspectiva que dê ênfase ao ensino de gramática normativa, definida como "um manual de regras de bom uso da língua a serem seguidas por aqueles que querem se expressar adequadamente" (Travaglia, 2009, p. 27). Segundo o autor, os usos da língua que não atendem a essas regras são considerados "desvios, erros, deformações, degenerações da língua" que devem ser corrigidos na/pela escola. Mesmo assim, não se pretende defender aqui que não se trabalhe com gramática normativa, já que isso iria contra uma tradição de ensino ainda valorizada em nossa sociedade, e sim, seguindo a proposta de Câmara e Abreu-Tardelli (2014), que se diminua a importância dada ao 
ensino desse tipo de gramática, englobando também os outros tipos de gramática propostos por Travaglia $(2009$; 2011), que, segundo as autoras, são mais importantes para o ensino da leitura e da escrita.

Travaglia (2011) conceitua, além da gramática normativa, mais três tipos de gramática que também devem ser trabalhados na escola: (i) gramática descritiva, que compreende a descrição das unidades e categorias linguísticas de determinada variedade da língua, por meio da observação e levantamento de hipóteses pelo linguista; (ii) gramática reflexiva, que diz respeito ao processo de levantamento das unidades, regras e princípios constitutivos da língua em funcionamento, buscando-se a compreensão da gramática implícita do falante; (iii) gramática teórica, que abrange tanto os estudos linguísticos, no que diz respeito à metalinguagem e à estruturação, conceituação e funcionamento da língua, como a parte mais descritiva das gramáticas normativas. A importância do ensino desse tipo de gramática é prover o aluno de metalinguagem suficiente que lhe possibilite de modo mais fácil referir-se aos recursos linguísticos durante o aprendizado dos outros tipos de gramática.

Defende-se, neste trabalho, portanto, uma perspectiva sobre o ensino de gramática que vai além do ensino de gramática normativa, que se limita majoritariamente ao ensino de regras prescritivas, de nomenclatura e de metalinguagem. O ensino de gramática deve ser uma prática reflexiva sobre e descritiva do uso dos recursos linguísticos, o que pode contribuir para o desenvolvimento no aluno das competências de leitura e de escrita. Para tanto, nossa proposta considera o funcionamento da oração subordinada adjetiva, segundo a perspectiva do estudo discursivofuncional de Câmara (2015), que será exposto na próxima seção. Essa perspectiva é escolhida devido ao fato de ver a gramática não apenas a partir de seus aspectos formais, mas também semânticos e pragmáticos, o que está em consonância com as atuais propostas de ensino de gramática.

\subsection{Descrição discursivo-funcional da oração subordinada adjetiva}

A Gramática Discursivo-Funcional (Hengeveld e Mackenzie, 2008) é uma teoria funcionalista organizada de modo hierárquico e descendente em quatro níveis, a saber, pragmático, semântico, morfossintático e fonológico. Os níveis se encontram organizados segundo a seguinte 
direção: o nível pragmático governa o semântico, ambos governam o morfossintático, e os três governam o fonológico.

O nível pragmático diz respeito aos aspectos formais da unidade linguística que refletem seu papel na interação entre falante e ouvinte (Hengeveld e Mackenzie, 2008, p. 46). Em outras palavras, este nível descreve apenas os aspectos interpessoais das unidades linguísticas que são codificados na mensagem, e não quaisquer outros aspectos que não têm expressão na gramática de certa língua. A unidade de análise que contém todo o conteúdo comunicado proferido pelo falante denomina-se ato discursivo. A oração subordinada adjetiva explicativa difere da oração subordinada adjetiva restritiva, na medida em que a primeira se define pragmaticamente, e a segunda se define semanticamente. Consideremos as orações subordinadas adjetivas destacadas no texto a seguir, para discutir os conceitos aqui apresentados.

\section{As supermães e as mães normais [...]}

Há quase 16 anos no ramo da maternidade, com duas experiências bem sucedidas até aqui, me pergunto: o que fiz que merecesse ficar como exemplo para a posteridade? $\mathrm{Ok}$, passei noites em claro, troquei muitas fraldas, levei e busquei do colégio umas 3 mil vezes - e ainda sigo na função. Fui a festinhas de aniversário barulhentas, passei fins de semana em pracinhas, ensinei a andar de bicicleta, levei a livrarias e cinemas, fiz vários curativos, impus limites, disse "não" quando era preciso e até quando não era preciso. Nada que uma mãe média também não faça.

O que elas aprenderam comigo? A devolver o que é seu, a dizer a verdade, a ser gentil, a não depender demais dos outros, a aceitar que as pessoas não são todas iguais e que isso é bom. Nem mesmo as mães são todas iguais, contrariando o famoso ditado. Há as que se sacrificaram, as que abriram mão de sua felicidade em troca da felicidade dos filhos, as que mantiveram casamentos horrorosos para não fazê-los sofrer com um lar desfacelado, as que trabalharam insanamente para não faltar nada em casa, as que sangraram por dentro e por fora para manter a família de pé. 
Eu não fiz nada disso. Por sorte, a vida não me exigiu nenhuma atitude sobre-humana. Fui e sigo sendo uma mãe bem normalzinha. Que acerta, que erra, que faz, o melhor que pode. Em comum com as supermães, apenas o amor, que é sempre inesgotável. Mas, medalha de honra ao mérito, não sei se mereço. Não me julgo sacrificada e tampouco sublime. Sou uma mulher que teve a sorte de ter a Julia e a Laura, uma mulher que se equilibra entre dividas e certezas e que consegue tirar um saldo positivo desta adorável bagunça. [...]

(Texto de Martha Medeiros extraído do livro Português: linguagens em conexão, 2013, p. 325)

A adjetiva explicativa destacada no enunciado "Em comum com as supermães, apenas o amor, que é sempre inesgotável' é formulada como um ato discursivo. O status de ato da adjetiva explicativa comprova-se pelo fato de ser pronunciada com status ilocucionário e contorno entoacional independentes do sintagma nominal:

(1) Em comum com as supermães, [tenho] apenas o amor, que é sempre inesgotável?

Observa-se que a ilocução interrogativa atinge apenas o conteúdo do ato nuclear constituído pela oração principal (tenho apenas o amor em comum com as supermães?), enquanto a oração subordinada adjetiva contém ilocução declarativa (não se questiona o fato de o amor ser sempre inesgotável), o que comprova que são dois atos com diferentes ilocuções. Outro argumento que comprova que são atos distintos é dado por Câmara (2015), em que se defende que a adjetiva explicativa é pronunciada com tessitura mais baixa e velocidade mais rápida que o contexto linguístico em que se insere.

Sendo formulada pragmaticamente, a adjetiva explicativa recebe a função retórica de aposição, de atribuir informação de fundo sobre o núcleo nominal. No exemplo (1), atribui-se ao amor a qualidade de ser inesgotável. Isso significa que a adjetiva explicativa traz informação adicional, acessória, com relação às outras informações da sentença. Mas isso também quer dizer que contém uma função argumentativa fundamental. É justamente 
o fato de ser inesgotável que identifica a locutora com o grupo das supermães, aquelas que realizam sacrifícios sobre-humanos para educar e criar os filhos. A intenção comunicativa da escritora é deixar claro ao leitor que, apesar de ser uma mãe normal, merece o rótulo de supermãe devido à intensidade do amor que sente pelas filhas. Só não se sacrificou tanto por elas, porque teve muita sorte na vida.

Já o nível semântico lida com os aspectos semânticos das unidades linguísticas, que são descritas em termos da natureza designativa; em outras palavras, esse nível é responsável pelos aspectos semânticos das unidades linguísticas, independentemente da maneira como são usadas na comunicação. Nesse sentido, a oração subordinada adjetiva restritiva define-se semanticamente como um modificador de núcleo nominal. Vejamos o exemplo (2).

(2) Nem mesmo as mães são todas iguais, contrariando o famoso ditado. Há as que se sacrificaram, as que abriram mão de sua felicidade em troca da felicidade dos filhos, as que mantiveram casamentos horrorosos para não fazê-los sofrer com um lar desfacelado, as que trabalharam insanamente para não faltar nada em casa, as que sangraram por dentro $e$ por fora para manter a família de pé.

As orações adjetivas restritivas em (2) especificam o núcleo nominal mães, contribuindo para que o leitor faça a escolha adequada do referente. Há um conjunto formado por todas as mães, dentro do qual se especificam subconjuntos (das mães que se sacrificaram, das que abriram mão de sua felicidade etc.). A adjetiva restritiva tem como objetivo levar o leitor, por meio da formulação adequada do referente, a identificá-lo dentre um conjunto infinito de referentes possíveis (Dik, 1997).

O nível morfossintático, por sua vez, é responsável por receber o input dos níveis pragmático e semântico e representá-los estruturalmente. Em termos de codificação morfossintática, não há diferença entre os dois tipos de adjetivas, o que se deve ao fato de que, em ambas, um sintagma nominal recruta uma oração para formar uma estrutura mais complexa. Isso significa que tanto a adjetiva restritiva como a adjetiva explicativa estão subordinadas ao sintagma nominal que modificam, o que esclarece a confusão de alguns LD de Ensino Fundamental em que a oração subordinada adjetiva é vista como subordinada a outra oração (cf. Pezatti e Câmara, 2014). 
Enfim, o último nível do componente gramatical, o nível fonológico, codifica as estruturas morfossintáticas em construtos fonológicos, conferindo uma codificação prosódica diferente para cada tipo de oração subordinada adjetiva. Enquanto a adjetiva explicativa contém um contorno entoacional próprio que a define como um sintagma entoacional, a adjetiva restritiva é codificada como um sintagma fonológico que, juntamente com o núcleo nominal, forma um único sintagma entoacional (cf. Câmara, 2015).

Nessa seção, aponta-se para a importância de se considerarem também os aspectos pragmáticos ao se diferenciar a adjetiva restritiva da explicativa. Isso deve ser levado em conta, ao considerarmos os efeitos de sentido mobilizados pelos diferentes tipos de oração subordinada adjetiva.

\section{METODOLOGIA}

$\mathrm{Na}$ tabela abaixo, elencam-se as coleções que serão analisadas neste estudo.

\section{Livros didáticos}

Português: contexto, interlocução e sentido (Abaurre, Abaurre e Pontara, 2013)

Português: linguagens (Cereja e Magalhães, 2013)

Lingua Portuguesa: linguagem e interação (Faraco, Moura e Maruxo Jr., 2013)

Ser Protagonista: língua portuguesa (Ramos, 2013)

Português: linguagens em conexão (Sette, Travalha e Barros, 2013)

O critério para escolha dessas coleções foi a aprovação no Programa Nacional do Livro Didático (PNLD-2015). Parte-se do pressuposto de que o livro didático, desde sua implantação em 19 de agosto de 1985 pelo Ministério da Educação (MEC), por meio do Decreto-Lei n. ${ }^{\circ}$ 91.542, é um importante material de pesquisa para os professores e, por isso, é um dos materiais mais utilizados na sala de aula.

$\mathrm{Na}$ análise dos livros didáticos, parte-se das propostas de ensino de gramática apresentadas nos manuais para o professor (Manual do Professor, doravante MP), que se encontram anexados no final da obra e em que estão os pressupostos teóricos subjacentes à elaboração do material didático. 
Segundo os MP, a contextualização dos aspectos linguísticos é um dos pressupostos mais importantes. Propõe-se que o ensino de gramática enfoque a reflexão sobre os recursos linguísticos, para a compreensão dos efeitos de sentido produzidos, ou seja, deve-se levar o aluno à compreensão do funcionamento dos recursos linguísticos no texto, usados intencionalmente pelo falante para produzir determinados efeitos de sentido. Essa opção teórica pressupõe que os recursos linguísticos sejam estudados no texto, e não em exemplos isolados.

Ao mesmo tempo em que buscam inovar o ensino de gramática, partindo dos pressupostos das novas teorias da linguagem, os manuais reconhecem o conteúdo da gramática tradicional como um saber necessário à formação linguística do aluno. Como um saber sociocultural validado positivamente pela sociedade, é consenso entre os pesquisadores a importância de se trabalhar com esse conhecimento na escola. Isso leva à necessidade de se posicionar perante duas questões: o uso de metalinguagem e a nomenclatura tradicional. A posição dos manuais é construir uma metalinguagem que seja um recurso auxiliar de referência aos recursos linguísticos e que sirva à interpretação e à produção de textos. $\mathrm{O}$ manual Lingua portuguesa: linguagem e interação, por exemplo, declara desenvolver no aluno a criação de uma metalinguagem, cujo objetivo é facilitar a referência aos fenômenos linguísticos, o que possibilita ao professor lançar mão da nomenclatura no momento da avaliação das produções de texto. Ademais, os manuais se propõem a modificar o modo como o conteúdo gramatical tradicional é inserido nos LD, não mais de forma incisiva, e sim problematizadora, questionando-se a validade das regras da gramática tradicional. O manual Ser protagonista: língua portuguesa afirma procurar ultrapassar incoerências e contradições da gramática tradicional, promovendo a reflexão crítica e o pensamento científico. Já a proposta do manual Português: linguagens em conexão é contrastar a tradição gramatical com a descrição do estágio atual da língua, realizando uma reflexão não apenas morfossemântica, mas também pragmática, levando os alunos a perceberem que, a depender do contexto, um mesmo enunciado pode apresentar sentidos diferentes.

Para promover o desenvolvimento da capacidade de reflexão sobre a língua, os LD propõem a articulação entre gramática e leitura/produção de textos, defendendo que o estudo de gramática só tem relevância se objetivar o desenvolvimento das habilidades de leitura e escrita. Tal postura leva à articulação entre o ensino de gramática e as características 
dos gêneros textuais em estudo. Apesar dessa preocupação, a maioria dos LD organizam os conteúdos de língua portuguesa em seções ou capítulos distintos. Lingua portuguesa: linguagem e interação é o único LD analisado que se propõe a unir de maneira articulada e global os estudos sobre a língua com o estudo da leitura/produção de textos. Devido a essa opção dos escritores, nem sempre os conteúdos gramaticais estão dispostos na obra da forma tradicional; as orações subordinadas adjetivas, por exemplo, são tratadas no $2 .^{\circ}$ ano, e não no $3 .^{\circ}$, como se faz comumente, por causa do foco que se dá nesse volume ao gênero romance, em que a função linguísticodiscursiva de caracterização sobressai-se na construção do gênero.

Deriva da opção por relacionar o ensino de gramática à escrita o fato de o ensino dos recursos linguísticos terem como resultado final a produção de texto. Nesse sentido, o manual Lingua portuguesa: linguagem e interação tem como proposta para o ensino de gramática tanto a reflexão sobre o uso da língua nas atividades de leitura e interpretação de textos como a produção de textos orientada com base na "utilização das estruturas linguístico-discursivas e gramaticais estudadas" (Faraco, Moura e Maruxo Jr., 2013, p. 399). O manual Português: contexto, interlocução e sentido também defende que os alunos, após terem estudado determinado tópico gramatical, realizem atividades de produção textual, em que possam usar os recursos aprendidos de modo "intencional e consciente" (Abaurre, Abaurre e Pontara, 2013, p. 17). O manual Português: linguagens em conexão tem como proposta pedagógica que os conhecimentos linguísticos adquiridos sejam sistematizados na fase de produção e revisão de textos orais/escritos, visando à produção de determinado gênero discursivo. Por outro lado, o manual Português Linguagens propõe-se a estudar a língua em capítulos independentes, para que se ganhe "autonomia metodológica, maior espaço e importância” (Cereja e Magalhães, 2013, p. 444). Apesar dessa opção, a proposta dos autores é estudar as categorias gramaticais como responsáveis pela construção dos sentidos no texto, refletindo sobre seus valores semânticos e sobre os efeitos estilísticos produzidos, e não como pretexto para a identificação e classificação dessas categorias.

Considerando as concepções de ensino de gramática presentes nos manuais, busca-se entender a relação entre o ensino de gramática e o de leitura e escrita, investigando se o modo como a oração subordinada adjetiva é apresentada nos LD tem como objetivo o desenvolvimento das habilidades leitora e escritora. Para tanto, primeiramente, procede- 
se à leitura das seções referentes ao tema em estudo nos LD, para, a seguir, analisar-se qualitativamente tanto o conteúdo como as atividades apresentadas nos LD, orientando-se pelas seguintes perguntas:

1) As atividades de gramática relacionam-se aos aspectos temático, composicional e estilístico de algum gênero textual?

2) Os recursos linguísticos são estudados, tendo em vista a produção de efeitos de sentido no texto, tanto nas atividades de leitura como de escrita?

3) O tema é trabalhado a partir de frases descontextualizadas, seja na apresentação do conteúdo ou na proposição de atividades?

4) São apresentadas atividades que têm como foco apenas a identificação e a classificação dos recursos linguísticos?

\section{ANÁlISE DAS PROPOSTAS DE ENSINO DE ORAÇÃO SUBORDINADA ADJETIVA EM LIVROS DIDÁTICOS DO ENSINO MÉDIO: COMO SE DÁ A RELAÇÃO LEITURA, GRAMÁTICA E PRODUÇÃO TEXTUAL?}

Há de fato uma preocupação, na maioria dos LD, de se partir de um texto autêntico para o trabalho com a oração subordinada adjetiva. Quase todos os livros trazem no início da unidade um texto, que pode ser de diferentes gêneros textuais (história em quadrinhos, poema, cartaz), a partir do qual se inicia a reflexão sobre esse tópico gramatical. A exceção é o livro Lingua portuguesa: linguagem e interação, que parte diretamente da apresentação do conteúdo, exemplificando com frases extraídas de textos explorados na seção de Literatura, sem refletir sobre os sentidos produzidos pelo uso da oração subordinada adjetiva.

Nos outros quatro livros didáticos analisados, a apresentação da oração subordinada adjetiva inicia-se com um texto e questões de interpretação; não se relaciona, entretanto, o recurso linguístico aos efeitos de sentido produzidos. A seguir, apresentam-se perguntas que exigem do aluno a identificação e a classificação morfossintática da oração subordinada adjetiva ou do pronome relativo, ou sua classificação em 
restritiva ou explicativa. Vejamos as atividades em (3)-(5), extraídas de Cereja e Magalhães (2013, p. 77-78), sobre o poema "Perde e ganha" de Ferreira Gullar.

\section{Perde e ganha}

Vida tenho uma só

que se gasta com a sola do meu sapato

a cada passo pelas ruas

e não dá meia-sola.

Perdi-a já

em parte

num pôquer solitário,

mas ganhei de novo

para um jogo comum.

E neste jogo a jogo

inteira, a cada lance,

que a vida ou se perde ou se ganha com os demais

e assim se vive

que o mais é pura perda.

(Gullar, F. Toda poesia. 18 ed. Rio de Janeiro: José Olympio; 2009. p. 172)

(3) Na primeira estrofe do poema há um período composto por subordinação. Observe: "Vida tenho uma só que se gasta com a sola do meu sapato".

A oração que se gasta com a sola do meu sapato está subordinada à oração anterior por meio do conectivo que, um pronome relativo.

(a) Que palavras, expressas anteriormente, esse conectivo retoma e substitui? Resposta: uma vida.

(b) Substitua o pronome relativo que pelas palavras que são retomadas por ele. Que função sintática essas palavras desempenham na oração que se gasta com a sola do meu sapato?

Resposta: A função de sujeito. 
(4) $O$ período composto analisado na questão anterior também poderia ter sido construído assim: Tenho só uma vida, gasta com a sola do meu sapato.

(a) Nesse período, qual é a classe gramatical da palavra gasta?

Resposta: Classe dos adjetivos.

(b) Que função sintática a palavra gasta desempenha?

Resposta: A de predicativo do objeto.

(5) No poema "Perde e ganha", o eu lírico reflete sobre a vida e compara-a a um jogo.

(a) Que expressões do campo semântico de jogo são utilizadas para construir essa comparação?

Resposta: "Perde e ganha”, "perdi-a já/em parte/num pôquer”, "mas ganhei de novo/para um jogo comum", "E neste jogo a jogo".

(b) Nesse jogo, o eu lírico prefere o jogo solitário ou o jogo coletivo? Por quê?

Resposta: O jogo coletivo (“jogo comum”), pois no "pôquer solitário” acabou por perder parte de sua vida.

Em (3) e (4), as atividades partem de conteúdos gramaticais (pronome relativo, sujeito, adjetivo, predicativo do objeto) já apresentados anteriormente aos alunos. São atividades de identificação e classificação dos recursos linguísticos que não promovem a reflexão sobre a construção dos sentidos do texto. Em (5), por sua vez, há exercícios de identificação de informações explícitas no texto. Não há, no entanto, uma relação entre o uso dos mecanismos de leitura e o uso da oração subordinada adjetiva.

Há duas atividades nos livros analisados que diferem dessas na apresentação do conceito de oração subordinada adjetiva.

No livro Português: contexto, interlocução e sentido (Abaurre, Abaurre e Pontara, 2013, p. 235-236), a reflexão focaliza o funcionamento do pronome relativo em uma história em quadrinhos. Pede-se, além da classificação morfossintática de que, que o aluno explique como o pronome relativo participa da construção dos sentidos do texto, mostrando que esse recurso linguístico permite a criação de um efeito de circularidade entre os acontecimentos. 
(6) Um piolho pica a cabeça de um garoto e isso desencadeia uma série de acontecimentos que levam à morte do inseto. Que relação existe entre esses acontecimentos? Como você identificou essa relação?

Resposta: A leitura atenta dos quadrinhos permite identificar uma relação de encadeamento entre os vários acontecimentos. A relação de encadeamento de ações fica evidente quando se constata que cada novo acontecimento é desencadeado pelo anterior.

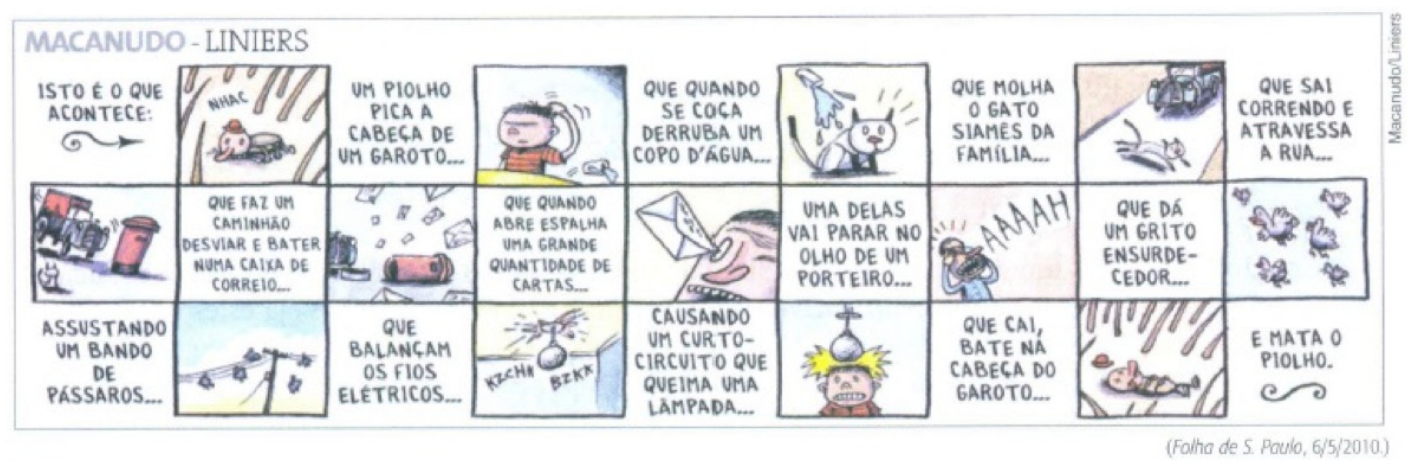

(7) Releia e compare a função dos termos destacados.

"[Um garoto] derruba um copo d'água... que molha o gato siamês da família... que sai correndo e atravessa a rua... que faz um caminhão desviar e bater numa caixa de correio... que [...] espalha uma grande quantidade de cartas..."

(a) A que classe de palavras pertence o termo que destacado acima? Explique.

Resposta: Os termos destacados (que) são pronomes relativos. Isso fica evidente quando observamos que ele substitui seu antecedente, introduzindo uma nova oração.

(b) Que função sintática esse termo exerce nessas orações?

Resposta: Em todas as ocorrências do trecho transcrito, o pronome relativo exerce a função sintática de sujeito.

(8) De que modo o termo destacado participa da construção da relação entre os vários acontecimentos apresentados na tira? Podemos afirmar que a escolha da estrutura

Câmara, AL. A oração subordinada adjetiva na produção de sentidos no texto... 
sintática presente no texto da tira possibilitou a criação de um efeito de circularidade entre os acontecimentos. Explique por quê.

Resposta: Por se tratarem de pronomes relativos que recuperam um antecedente anteriormente expresso, esses termos permitem construir uma série de orações encadeadas. É dessa forma que participam do estabelecimento da relação entre os acontecimentos apresentados na tira. É o fato de ter uma série de orações encadeadas pelo uso dos pronomes relativos que faz com que a relação expressa no início da tira entre o garoto e o piolho na cabeça do garoto desencadeia as várias ações que culminam com a queda da lâmpada na cabeça desse mesmo garoto, provocando a morte do piolho. Estabelece-se, assim, o efeito de circularidade entre os acontecimentos apresentados na tira.

$\mathrm{Na}$ interpretação da HQ, o aluno é levado a perceber que o pronome relativo serve para recuperar um antecedente expresso anteriormente. A cada nova oração, o último referente introduzido é retomado pelo pronome relativo (garoto - copo d'água - gato - rua - caixa de correio e assim sucessivamente), causando um efeito de circularidade no último quadrinho ao retomar-se o referente piolho. Deve-se atentar para o fato de que não é apenas o pronome relativo que causa o efeito de circularidade, e sim a justaposição das ações, até no final a última ação desencadear uma consequência (a morte) para o piolho que desencadeou a série de ações. Qualquer outro recurso de coesão poderia ter sido usado para retomar as informações já referidas, sem que se alterasse o efeito de circularidade, como a repetição do termo (Um piolho pica a cabeça de um garoto. Quando o garoto se coça, derruba um copo d'água etc.), ou o uso de um pronome demonstrativo (Um piolho pica a cabeça de um garoto. Quando este se coça, derruba um copo d'água etc.).

Já o livro Português: linguagens em conexão é o único que, na apresentação do conteúdo, tenta estabelecer uma relação entre os três pilares: leitura gramática - produção textual. Após a leitura de um cartaz sobre a saúde dos homens, propõem-se algumas atividades de identificação dos elementos desse gênero textual (objetivo, público alvo, relação entre linguagem verbal e não-verbal), como se observa a seguir: 
(9) Leia o cartaz a seguir.

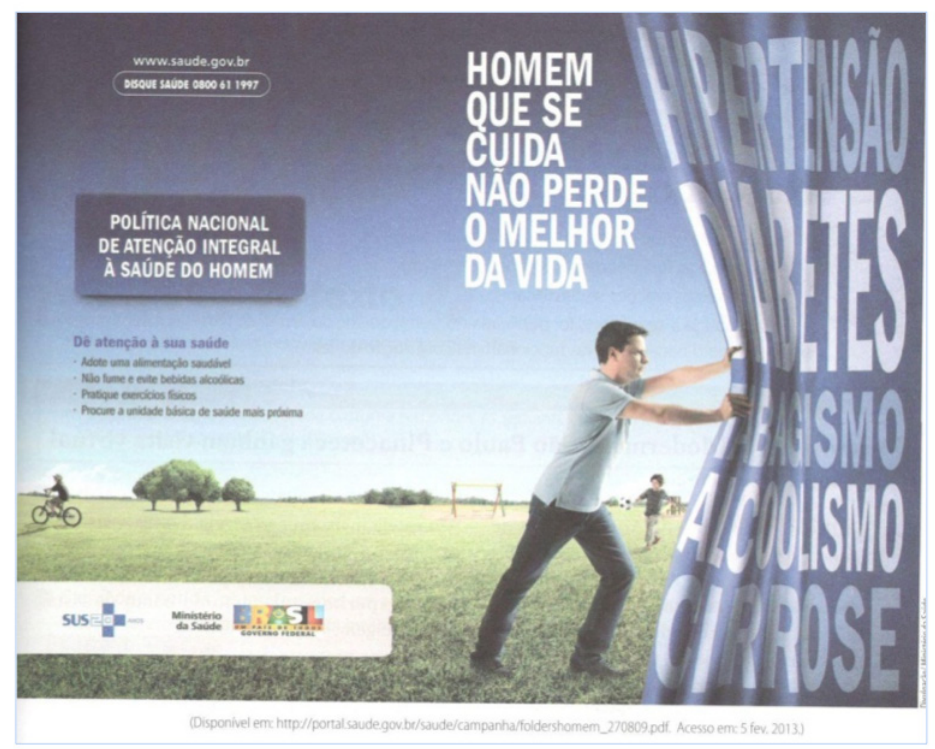

(a) Qual é o objetivo e o público-alvo desse cartaz?

Alertar os homens a respeito dos perigos da má alimentação, do tabagismo, do alcoolismo, do sedentarismo e da falta de cuidados com a saúde. A campanha é dirigida aos homens porque - segundo estatísticas - eles são mais resistentes às consultas e aos tratamentos médicos.

(b) Em sua opinião, a quem mais essa campanha deve ser destinada?

Resposta pessoal. Comente com os alunos que os problemas de saúde apontados na campanha não se restringem aos homens. Com a emancipação feminina, as mulheres entraram no mercado de trabalho e adotaram o mesmo estilo de vida que os homens, o que tem provocado esses mesmos problemas de saúde.

(c) Que tipos de linguagem são usados no cartaz? Explique.

A linguagem verbal e a linguagem não verbal (logotipos de instituições governamentais, imagem de uma criança brincando em cenário diurno, ao ar livre, e de um homem que empurra uma cortina onde estão escritas as palavras "hipertensão, diabetes, tabagismo e cirrose").

Câmara, AL. A oração subordinada adjetiva na produção de sentidos no texto... 
(d) Como você interpreta a imagem da cortina sendo empurrada pelo homem?

A cortina representa os males que atacam o homem que não se cuida. Com o descortinamento, vê-se um campo gramado, com alguns brinquedos, onde uma criança brinca feliz. Isso sugere "o melhor da vida", uma vida alegre e saudável de quem se livra desses males. Comente que a cortina representa esses males que impedem a pessoa a ter acesso a uma vida saudável e feliz.

(e) Leia a mensagem abaixo e observe que ela é formada por uma oração principal e por uma oração subordinada que está intercalada à principal.

"Homem que se cuida não perde o melhor da vida."

Qual é a oração principal? E a oração subordinada intercalada?

"Homem não perde o melhor da vida": oração principal; "Que se cuida": oração subordinada adjetiva.

(f) Qual é a função da oração subordinada adjetiva? Explique.

Ela está limitando, restringindo o tipo de homem que "não perde o melhor da vida", que é aquele "que se cuida".

(g) Construa mensagens a respeito das consequências do tabagismo, do alcoolismo e do sedentarismo. Use a mesma estrutura sintática da mensagem da campanha: oração principal + oração subordinada adjetiva intercalada. A mensagem deve ser dirigida a pessoas em geral. (Sette, Travalha e Starling, 2013, p. 319-320)

$\mathrm{Na}$ atividade (9), o livro propõe uma reflexão sobre o uso da oração subordinada adjetiva, tendo como objetivo que o aluno perceba a função delimitativa da adjetiva restritiva. Na sequência, propõe-se que se construam mensagens semelhantes à do texto analisado sobre outras temáticas, usando a mesma estrutura sintática explorada no cartaz original (oração subordinada adjetiva). No entanto, o aluno não é orientado para a escrita de um texto de determinado gênero e para atender determinada finalidade sociodiscursiva, o que pode resultar em uma atividade de produção textual mecânica e artificial. 
Após essas atividades de apresentação do conteúdo gramatical, os LD expõem mais detalhadamente as características semânticas e morfossintáticas das orações subordinadas adjetivas, a partir de frases extraídas de textos autênticos ou inventados. A oração subordinada adjetiva se caracteriza por ser introduzida por pronome relativo e por funcionar como um adjunto adnominal/adjetivo do nome/da oração principal à qual está subordinada. Afirmar que a oração adjetiva está subordinada à oração principal é uma concepção equivocada sobre a relação de subordinação das adjetivas, apresentada pela maioria dos LD, já que, como explicado na seção 2.1 , a oração subordinada adjetiva se subordina ao núcleo nominal, que pode ou não estar dentro de uma oração. No texto "As supermães e as mães normais", citado naquela seção, há diversas orações adjetivas subordinadas a um sintagma que não pertence a nenhuma oração principal, como "uma mulher que se equilibra entre dívidas e certeras e que consegue tirar um saldo positivo desta adorável bagunça". Outro equívoco dos livros didáticos é dizer que a oração subordinada adjetiva modifica um substantivo, quando os próprios exemplos dados pelos LD mostram que a oração pode estar subordinada a um pronome (núcleo vazio) ${ }^{1}$. O terceiro equívoco, presente em dois LD, é que a oração subordinada adjetiva funciona como um adjunto adnominal, quando na realidade a adjetiva explicativa desempenha uma função, em termos tradicionais, mais próxima ao Aposto. Esses equívocos também estão presentes em LD de Ensino Fundamental, conforme atestado por Câmara (2015).

Na distinção entre oração subordinada adjetiva restritiva e explicativa, os LD baseiam-se essencialmente em critérios semânticos. Enquanto a restritiva especifica, restringe, limita o sentido do antecedente, a explicativa acrescenta uma informação ou característica sobre o antecedente. Devese observar que não há consenso sobre o tipo de informação veiculada pela adjetiva explicativa: ora se afirma que veicula informação já conhecida pelo interlocutor (Cereja e Magalhães, 2013), ora que veicula informação suplementar sobre um termo já específico (Abaurre, Abaurre e Pontara, 2013), ora que veicula uma característica inerente, constitutiva do

\footnotetext{
1 Desde a perspectiva discursivo-funcional, o núcleo vazio (empty head) "engloba itens coesivos, como, por exemplo, pronomes demonstrativos, que se referem anaforicamente não a um item referencial, mas a um item semântico mencionado anteriormente" (Câmara e Pezatti, 2015).
} 
antecedente (Ramos, 2013). Primeiramente, a informação veiculada pela oração adjetiva explicativa não precisa necessariamente ser informação dada, como se percebe pelo próprio exemplo fornecido por Cereja e Magalhães (2013, p. 80): "A candidata, de quem temos excelentes referências, chegou para a entrevista". Nada indica que o interlocutor necessariamente já compartilhe a informação (ter excelentes referências sobre a candidata). Em segundo lugar, modificar núcleos específicos também não é uma característica intrínseca da oração adjetiva explicativa (Câmara e Pezatti, 2015), apesar de normalmente ser isso o que ocorre. A motivação para, diferentemente da restritiva, a explicativa modificar comumente núcleos específicos é que ela não tem a intenção de identificar o referente dentro de um conjunto de referentes possíveis.

A principal diferença entre a adjetiva restritiva e a explicativa diz respeito à formulação semântica e pragmática dessas construções, conforme exposto na seção 2.1. Enquanto a restritiva tem a função de identificar um referente dentre outros referentes possíveis, sendo formulada semanticamente; a explicativa tem o papel de acrescentar informações argumentativamente relevantes para se atingir os objetivos comunicativos do locutor. Segundo Pezatti e Câmara (2014), é preciso que essa diferença seja trabalhada com o aluno, o que só ocorre se consideradas em textos autênticos. As autoras também afirmam que isso pode se dar a partir de atividades de gramática reflexiva, em que o aluno é levado à percepção do uso desse recurso linguístico na construção do texto.

Após a conceituação da oração subordinada adjetiva, os LD apresentam atividades para exercitação dos conteúdos apresentados. Tais atividades podem ser exclusivamente de identificação e classificação morfossintática e semântica, como no livro Lingua Portuguesa: linguagem e interação. Normalmente, essas atividades partem de frases descontextualizadas ou isoladas do texto a que pertencem, como exemplificado pela atividade do livro Português: linguagens em conexão:

(10) Qual é a diferença de sentido entre estes enunciados?

a) Os materiais que são recicláveis devem ser aproveitados.

b) Os materiais, que são recicláveis, devem ser aproveitados. 
Resposta: O primeiro período (a), que apresenta uma oração adjetiva restritiva, marcada pela ausência de vírgulas, informa que uma parte do material é reciclável e que somente essa parte deve ser aproveitada. O segundo período (b), que apresenta uma oração adjetiva explicativa, separada por vírgulas, informa que todo o material é reciclável e deve ser totalmente apresentado. (Sette, Travalha e Starling, 2013, p. 324)

(11) Os pronomes relativos podem exercer as seguintes funções sintáticas: sujeito, objeto direto, objeto indireto, complemento nominal, predicativo do sujeito, adjunto adnominal e agente da passiva. Classifique as orações introduzidas pelos pronomes relativos e a função sintática exercida por eles:

a) Este é o prédio em que moro.

Que: introduz oração adjetiva restritiva e funciona como adjunto adverbial.

b) Li um artigo que trata da influência da mídia na formação dos adolescentes.

Que: introduz oração adjetiva restritiva e funciona como sujeito.

c) Era interessante o texto de que falava.

Que: introduz oração adjetiva restritiva e exerce função de objeto indireto.

d) Estas são as normas que você deve seguir.

Que: introduz oração adjetiva restritiva e exerce função de objeto direto. (Sette, Travalha e Starling, 2013, p. 324)

A primeira atividade visa à identificação da diferença semântica entre a adjetiva restritiva e a explicativa, enquanto a segunda exige a identificação e classificação sintática da oração adjetiva e do pronome relativo. Em ambas, os exemplos analisados são inventados, e não autênticos.

Também há atividades que visam tanto à interpretação do texto quanto à identificação e classificação da oração subordinada adjetiva e do pronome relativo, sem que haja uma relação entre o uso do recurso gramatical e a produção de sentidos no texto, como nas atividades do livro Português linguagens sobre o anúncio a seguir:

Câmara, AL. A oração subordinada adjetiva na produção de sentidos no texto... 


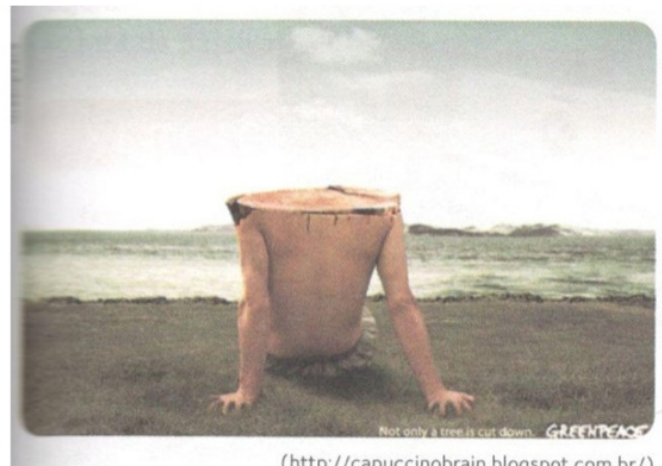

(http://capuccinobrain.blogspot.com.br/)

Em português, o texto do anúncio é “Não é só uma árvore que está sendo cortada”.

(12) O anúncio foi publicado pelo Greenpeace, uma ONG (organização não governamental) que luta em defesa do meio ambiente. Observe a imagem e o enunciado verbal do anúncio.

(a) Como é o ambiente retratado na imagem? Descreva-o.

Trata-se de um ambiente natural, à beira-mar, mas sem nenhuma árvore.

(b) A figura em destaque na imagem representa uma simbiose entre dois seres vivos. Quais são eles?

A espécie humana e as árvores.

(c) Por que, no anúncio, a figura em destaque na imagem e o enunciado verbal se complementam?

O enunciado menciona árvores que estão sendo cortadas e a figura representa um ser humano com o tronco cortado.

(d) Que interpretação pode ser dada ao anúncio como um todo?

A simbiose homem-árvore sugere que, com a derrubada de árvores, não se destrói apenas uma espécie natural, mas todo o meio ambiente, incluindo os animais (entre eles, o ser humano), que fazem parte do meio ambiente.

Câmara, AL. A oração subordinada adjetiva na produção de sentidos no texto... 
(13) No enunciado verbal do anúncio, há duas orações. Identifique e classifique cada uma delas.

Não é só uma árvore: oração principal; que está sendo cortada: oração subordinada adjetiva restritiva. (Cereja e Magallhães, 2013, p. 81)

Enquanto a primeira atividade limita-se à interpretação e compreensão do anúncio, a segunda requer a identificação e classificação das orações adjetivas. Não há nenhuma reflexão sobre como o uso da oração subordinada adjetiva contribui para os sentidos estabelecidos no texto.

Em contrapartida, há atividades que tentam relacionar o uso da oração subordinada adjetiva tanto à leitura quanto à produção de texto. No livro Português: linguagens em conexão, apresenta-se uma atividade de produção textual em que o aluno também deve mobilizar seus conhecimentos sobre a função da oração subordinada adjetiva na construção do texto:

(14) Escreva um texto apresentando o que você considera como características de um "superfilho" e as características de um "filho normal, comum". O texto que você vai produzir deve seguir a estrutura sintática semelhante à dos trechos (destacados) da crônica lida: a caracterização desses "tipos de filhos" deve ser feita com orações subordinadas adjetivas. (Sette, Travalha e Starling, 2013, p. 325)

Verifica-se que a atividade está relacionada tematicamente com um texto em análise (texto reproduzido na seção 2.1), entretanto não há uma proposta detalhada que explicite o contexto de produção textual (gênero textual, público alvo, veículo de divulgação etc.), o que pode tornar a atividade artificial e mecânica (Câmara e Abreu-Tardelli, 2014). Atividades que relacionam a gramática à produção textual são raras nos livros analisados e restringem-se às citadas aqui, o que aponta para uma necessidade de se pensar mais sobre como essa relação pode ser implementada pelos materiais didáticos, visto que é uma exigência 
apontada nos documentos oficiais (Brasil, 1998; Brasil, 2015²) que regulam o ensino da língua portuguesa.

Quanto à díade leitura e gramática, as tentativas de se realizar uma reflexão sobre os efeitos de sentido provocados pelo uso da oração subordinada adjetiva são mais frequentes e diversas. Os livros Português: linguagens em conexão e Português linguagens exploram a função caracterizadora da oração subordinada adjetiva, com o objetivo de levar os alunos a perceberem seu uso na caracterização de nomes e pronomes, tal como o adjetivo. Vejamos a atividade a seguir sobre o poema "O leitor e a poesia", de Affonso Romano de Sant'Anna.

\section{O leitor e a poesia}

Poesia

não é o que o autor nomeia

é o que o leitor encendeia

Não é o que o autor pavoneia,

é o que o leitor colha à colmeia.

Não é o ouro na veia

é o que vem na bateia.

Poesia

não é o que o autor dá na ceia,

mas o que o leitor banqueteia.

(Affonso Romano de Sant'Anna. Melhores poemas. 3. ed. Seleção de Donaldo Schüler. São Paulo: Global, 1997, p. 150)

$\overline{2}$ A Base Nacional Comum Curricular (BNCC) foi divulgada em setembro de 2015, propondo um currículo unificado para todo o território brasileiro. Tal proposta surtiu diversos debates na mídia pela tentativa de inovação no tratamento da gramática. A Folha de São Paulo, em 11 de outubro de 2010, expôs a polêmica encabeçada pelo ministro da Educação, Aloizio Mercadante, que declarou a necessidade de dar mais ênfase ao ensino da norma culta nas escolas. A repercussão na mídia e na sociedade sobre a nova proposta aponta a necessidade de mais discussões sobre o assunto a partir dos resultados de pesquisadores sobre um ensino mais reflexivo da língua portuguesa, em prol de romper com a concepção tradicional de ensino de gramática que prevalece midiática e socialmente. A BNCC está disponível para debate púbico no site: http://basenacionalcomum.mec.gov. br.

Câmara, AL. A oração subordinada adjetiva na produção de sentidos no texto... 
(15) Observe que tanto o pronome relativo quanto a oração adjetiva têm fundamental importância na construção dos sentidos do poema.

(a) Como se classificam as orações adjetivas empregadas no texto?

Orações subordinadas adjetivas restritivas.

(b) Considerando o tema e a finalidade do poema, responda: por que as orações adjetivas foram empregadas com tanto destaque?

Como o objetivo do poeta é definir o que é poesia, é natural que empregue expressões apropriadas para indicar características, como adjetivos e ou orações adjetivas. No caso, ele optou por orações adjetivas. (Cereja e Magalhães, 2013, p. 85)

Nesta atividade, o leitor é levado a refletir sobre a função da oração subordinada adjetiva na caracterização do substantivo poesia. Apesar de se apontar uma equivalência entre o uso do adjetivo e da oração subordinada adjetiva, não há uma reflexão sobre a diferença entre o uso desses dois recursos gramaticais. A opção do autor por orações, ao invés de sintagmas, também poderia ter sido alvo de discussão (Pezatti e Câmara, 2014).

O livro Português: contexto interlocução e sentido, por sua vez, traz atividades em que se reflete sobre o uso da oração subordinada adjetiva e sua função caracterizadora na produção do efeito de humor no texto, como se verifica a seguir na história em quadrinhos de Calvin.
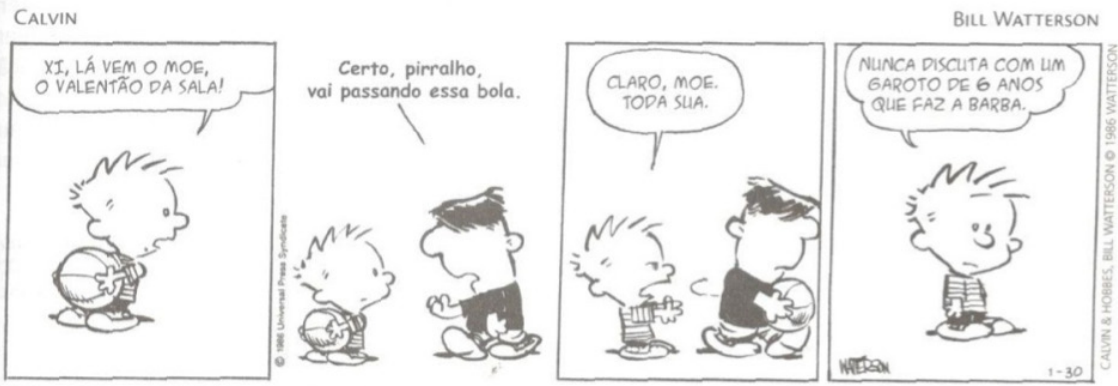

A WATTERSON, Bill. Calvin e Haroldo: e foi assim que tudo começou. Săo Paulo: Conrad Editora do Brasil, 2007. p. 39

(16) Na fala de Calvin no último quadrinho, há uma oração adjetiva. Transcreva no seu caderno essa oração e classifique-a.

A oração é que faz a barba, classificada como oração subordinada adjetiva restritiva. 
(17) Pode-se afirmar que o efeito de humor da tira está relacionado a essa oração adjetiva. Explique por quê.

Calvin destaca uma característica de Moe (ter a barba aos 6 anos de idade) por meio de uma oração adjetiva que explica o motivo de ter dado a sua bola ao valentão quando este ordenou. Como Moe é um menino forte e briguento, Calvin procura explicar o seu comportamento, aparentemente motivado pela covardia, afirmando que o garoto é fisicamente mais amadurecido do que outras crianças da mesma idade. O humor da tira decorre da justificativa inesperada de Calvin: pelo fato de Moe ser um garoto de 6 anos que já faz a barba, é melhor não discutir com ele. (Abaurre, Abaurre e Pontara, 2013, p. 241)

Para realizar esta atividade, o aluno deve não só perceber que a oração subordinada adjetiva caracteriza o personagem, mas também como essa característica contribui para se atingir o efeito semântico desejado, mostrar que o outro garoto é mais forte, o que justifica sua atitude "covarde" de entregar-lhe a bola.

Neste livro também há uma atividade sobre a função argumentativa da oração adjetiva explicativa. Câmara (2015) não identificou, em sua análise de livros didáticos de Ensino Fundamental, nenhuma referência a essa função da oração adjetiva explicativa. Dada a relevância dessa função na caracterização da adjetiva explicativa, a autora a aponta como um ponto importante a ser explorado nas aulas de língua materna. Vejamos o texto "O simples milagre da vida", em que as adjetivas explicativas são exemplificadas:

[...] A alquimia da transformação dos alimentos no fogo tem um espírito. E esse espírito começou a ocupar a minha casa, criando aconchego e a sensação de uma casa com vida própria. Quando se usa um micro-ondas, não se cozinha. A relação que temos com o alimento é bastante impessoal. $\mathrm{Na}$ comida congelada, o sabor já vem decidido e é o mesmo para todos. Os cheiros ficam embutidos. O tempo é programado. Mas, quando se trata de usar o fogão, nossos sentidos são todos instigados e nos envolvem no cuidado do alimento, no cuidado do que nos alimenta. Obrigam-nos à proximidade e à intimidade com tudo com que lidamos. Cozinhamos com os olhos - que comparam e procuram cores, movimentos, texturas-, com os ouvidos - que acompanham os 
sons da fervura, da cebola fritando-, com as mãos - que descobrem as consistências e as temperaturas-, com a boca e o nariz - que orientam na dosagem dos temperos e no ponto do aprontamento. Cozinhamos com a imaginação e com a curiosidade. E o tempo não é mais a duração fria e programada controlada pelos timers e relógios nem o da nossa mera expectativa. É um tempo de espera, em que nos empenhamos ativamente na preparação de um acontecimento. É um advento.

(Critelli D. Folha de S. Paulo. São Paulo, 25 de set 2003. Folha Equilíbrio. [Fragmento])

Sobre as orações destacadas, as autoras do LD propõem a seguinte atividade.

(18) Podemos afirmar que o uso dessas estruturas sintáticas recorrentes contribui para convencer o leitor de que é válida a opinião de Dulce Critelli sobre as diferenças entre o uso do micro-ondas e o do fogão, no preparo dos alimentos. Explique por que isso ocorre.

Como a intenção de Dulce Critelli é demonstrar a diferença entre o grau de envolvimento que tem alguém com o preparo dos alimentos quando usa um forno de micro-ondas (algo distante, impessoal) ou quando cozinha no fogão (algo envolvente, que instiga os sentidos), as orações subordinadas adjetivas explicativas desempenham uma importante função argumentativa: são elas que informam ao leitor do texto de que modo os olhos, os ouvidos, as mãos, a boca e o nariz do cozinheiro participam necessariamente do preparo dos alimentos em um fogão. (Abaurre, Abaurre e Pontara, 2013, p. 242)

Por meio dessa atividade, o aluno é levado a perceber que a oração adjetiva explicativa tem um funcionamento pragmático, que diz respeito às intenções do produtor do texto. Como a intenção é mostrar que cozinhar no fogão é melhor que usar um forno micro-ondas (o que nem é considerado como cozinhar), o escritor usa várias orações adjetivas explicativas para caracterizar os órgãos dos sentidos envolvidos no processo de cozimento no fogão. A função dessas orações não é delimitar o substantivo, como a adjetiva subordinada restritiva, e sim acrescentar informações que contribuam para convencer o leitor daquilo que o escritor está tentando provar (cozinhar no fogão é melhor). 
Desta perspectiva pragmática, o livro Ser protagonista: língua portuguesa também relaciona os sentidos veiculados pelo texto ao uso da oração subordinada adjetiva. $\mathrm{Na}$ atividade a seguir, o aluno deve perceber que a oração adjetiva restritiva desempenha o papel de especificar o núcleo, levando o leitor à identificação de um referente correto dentro de um conjunto de referentes possíveis. Vejamos:

(19) Examine as definições a seguir.

I. Cartão inteligente é uma lâmina plástica que possui um microprocessador em seu interior.

II. Pressão arterial é aquela que o sangue exerce contra as paredes das artérias.

(a) Qual é a importância dessas orações na definição de cartão inteligente e pressão arterial?

$\mathrm{Na}$ definição de cartão inteligente, a oração veicula uma informação essencial, pois lâmina plástica não é suficiente para definir o cartão inteligente: o que faz dessa lâmina inteligente é a presença do microprocessador; na definição de pressão arterial, a oração também é fundamental, porque é ela que traz a informação nova: o núcleo do predicativo do sujeito aquela apenas retoma o termo a ser definido (pressão arteriah).

(b) Com base em sua resposta anterior, você diria que a classificação dessas orações como "subordinadas" se baseia em um critério sintático ou semântico? Explique sua resposta.

Sintático. Nas definições I e II, as orações "que possui um microprocessador em seu interior" e "que o sangue exerce contra as paredes da artéria" modificam termos da oração principal, veiculando informações essenciais. (Ramos, 2013, p. 277)

Nesta atividade, propõe-se que a importância da oração adjetiva restritiva é acrescentar uma informação essencial para a construção do referente pelo leitor. Verifica-se, entretanto, que há uma incoerência na segunda atividade, em que o aluno é levado a refletir sobre o critério de subordinação dessas orações. Apesar de se afirmar que as orações adjetivas se subordinam sintaticamente a termos da oração principal, a própria explicação dada na primeira atividade mostra que a relação de dependência 
entre a oração adjetiva e o núcleo se estabelece pelo tipo de informação que é veiculado e que é indispensável inclusive para a gramaticalidade da sentença; portanto seria um critério essencialmente semântico que definiria a dependência que se estabelece entre o núcleo e a oração adjetiva. Essa questão pode levar a equívocos como o do livro didático referido e, devido à sua complexidade, não será tratada aqui (para mais detalhes consultar Câmara, 2015).

No livro Ser protagonista: lingua portuguesa, a diferença de uso entre a adjetiva restritiva e a explicativa é debatida a partir de suas funções na produção de sentidos no texto, como se verifica nas atividades a seguir.

(20) Releia este trecho.

Educador há mais de 37 anos e pai de Curtis - que morreu em consequência de uma vida inteira de bullying-, Allan Beane é hoje um militante da causa "mais respeito, por favor!".

(a) Qual é a importância dessa oração para a argumentação do texto?

O conteúdo da oração justifica o fato de Beane ter se tornado um militante da causa antibullying e também insere seu ponto de vista em um contexto: o de quem teve experiência direta com a situação, no papel de pai. Além de ser um fato que pode ser usado como base na argumentação do entrevistado.

(b) Em que outro momento do texto essa mesma informação é destacada?

$\mathrm{Na}$ linha fina da matéria: "Para professor que teve o filho morto por causa do bullying, a hostilidade na escola é disfunção de toda a sociedade."

(c) Em qual desses casos a informação tem mais força argumentativa: no trecho acima ou no identificado por você no item b.? Levante uma hipótese para explicar por quê.

A informação tem mais força argumentativa no item $b$. Apesar da semelhança de conteúdo, a forma como a informação é apresentada na linha fina não tem o mesmo poder argumentativo: ela apenas determina de que professor se trata. Isso ocorre porque, na linha fina, a informação não aparece em uma oração adjetiva explicativa, e sim em uma oração adjetiva restritiva. Já no caso do trecho em destaque, trata-se de uma oração adjetiva explicativa (Ramos, 2013, p. 278). 
Nesta atividade, o aluno é levado a perceber que a adjetiva restritiva tem função delimitadora e a adjetiva explicativa tem função argumentativa e se relaciona às intenções do produtor do texto. Esses usos são relevantes para se atingir os sentidos pretendidos: na linha fina, pretende-se apenas que o leitor identifique um professor específico dentro do conjunto de professores, ou seja, o enunciado se refere apenas àquele que teve o filho morto por causa do bullying. Já no corpo da notícia, essa mesma informação refere-se a Curtis, já suficientemente definido como nome próprio; portanto a função da adjetiva explicativa não é identificar um referente, e sim trazer, em termos argumentativos, uma informação relevante para se atingir os objetivos do escritor: como o filho foi vítima de bullying, o pai tem autoridade para falar sobre o tema e seus argumentos são verdadeiros e convincentes, isto é, o leitor deve acreditar no que ele diz ${ }^{3}$.

\section{CONSIDERAÇÕES FINAIS}

As propostas de ensino da oração subordinada adjetiva têm procurado, em alguns momentos e de modo inovador, ultrapassar o ensino tradicional de gramática. Em alguns LD de ensino médio, consideramse os aspectos pragmáticos na análise da oração adjetiva, ao se definir a adjetiva explicativa a partir de sua função argumentativa. Tal característica é fundamental para se compreender a diferença no uso entre os dois tipos de orações adjetivas. Essa posição é inovadora no sentido em que traz para o ensino as descobertas da análise linguística e ultrapassa um equívoco da gramática tradicional de diferenciá-las a partir de critérios essencialmente semânticos. No entanto, apenas dois LD trouxeram essa reflexão para a proposta de ensino da oração adjetiva, o que aponta para a necessidade de ampliar-se a reflexão sobre os aspectos pragmáticos da língua.

Os LD, em alguns momentos, tentam trabalhar com a gramática contextualizada, o que se verifica pela iniciativa de se partir de um texto autêntico na apresentação do conteúdo gramatical, mas se verificou que nem todos realizam esse trabalho e, quando o fazem, normalmente não

3 Na resposta sugerida no livro didático, há um equívoco, quando se afirma que a informação tem mais força argumentativa no item b. Mas esse equívoco é desfeito pela explicação que vem em seguida. A informação é argumentativamente mais forte no corpo da notícia (adjetiva explicativa), e não na linha fina (adjetiva restritiva).

Câmara, AL. A oração subordinada adjetiva na produção de sentidos no texto... 
levam a uma reflexão sobre a relação entre a oração subordinada adjetiva e os efeitos de sentido derivados de seu uso, o que demonstra que o (con)texto, muitas vezes, é usado apenas como pretexto para o ensino dos recursos linguísticos. Além disso, ainda há uma grande quantidade de frases inventadas e descontextualizadas. A conclusão a que se chega é que o ensino de gramática tem tomado como base as propostas para o ensino de gramática e as descobertas da análise linguística; entretanto, defendemos aqui, seguindo a proposta de Câmara e Abreu-Tardelli (2014), que essa iniciativa ainda pode ampliar-se mais e ganhar um foco maior, visando a diminuir as propostas essencialmente tradicionais que privilegiam atividades de identificação e classificação das unidades linguísticas.

As propostas de ensino de gramática devem dar maior ênfase à relação da gramática com a leitura e a produção textual, atendendo à diretriz das Orientações Complementares dos PCN para o Ensino Médio (Brasil, 2002), de que os recursos gramaticais devem ser subsidiários ao desenvolvimento das habilidades de leitura e de escrita. Desta perspectiva, este artigo defende a necessidade de se ampliar a reflexão sobre a relação entre a gramática e a produção textual, já que as propostas ainda são incipientes e pouco desenvolvidas, considerando-se a perspectiva dos gêneros textuais. Não há uma preocupação em se propor atividades de produção contextualizadas, em que se especifique o gênero textual, o público-alvo, a intenção do escritor, o contexto de produção, o veículo de publicação etc. As raras propostas de produção em que se pede para o aluno usar orações adjetivas são artificiais e mecânicas. Resultado semelhante é encontrado na análise de livros didáticos de Ensino Fundamental, por Câmara e Abreu-Tardelli (2014).

Deve haver, portanto, uma maior articulação entre o ensino de leitura, gramática e produção textual e isso deve ser feito considerandose o conceito de gêneros textuais, ainda pouco explorado no tocante ao ensino da oração subordinada adjetiva. Essa perspectiva pretende atender às diretrizes oficiais para o ensino de português (Brasil, 2002), em que se defende o abandono do esquema tradicional (narração, descrição e dissertação) e a adoção de um trabalho voltado aos gêneros textuais, abrangendo-se seus aspectos temáticos, composicionais e estilísticos. 


\section{REFERÊNCIAS}

Abaurre MLM, Abaurre MBM, Pontara M. Português: contexto, interlocução e sentido. 2.a ed. São Paulo: Moderna; 2013.

Bagno M. Nada na língua é por acaso: por uma pedagogia da variação linguística. São Paulo: Parábola Editorial; 2007.

Bagno M. Gramática pedagógica do português brasileiro. São Paulo: Parábola Editorial; 2011.

Bispo EB. Oração adjetiva cortadora: análise de ocorrências e implicações para o ensino de português. Linguagem \& Ensino. Pelotas 2007;10(1):163-186. Disponível em: http:// www.rle.ucpel.tche.br/index.php/rle/article/view/159. Acesso em: 01/09/2014.

Bispo EB, Silva JR. Análise linguística na educação básica: entre o real e o possível. Simpósio internacional de ensino de língua portuguesa. Uberlândia, SIELP EDUFU. 2011;1(1):282-294.

Brasil. Parâmetros Curriculares Nacionais (PCNs): língua portuguesa, ensino fundamental. Brasília: Ministério da Educação/Secretaria de Educação Fundamental; 1998. 107 f. Disponível em: http://portal.mec.gov.br/seb/arquivos/pdf/portugues.pdf. Acesso em: 10/10/2014.

Brasil. Parâmetros curriculares nacionais: ensino médio. Brasília: Ministério da Educação/ Secretaria de Educação Média e Tecnológica; 1999. 364 p.

Brasil. PCN+ Ensino Médio: Orientações Educacionais complementares aos Parâmetros Curriculares Nacionais. Linguagens, códigos e suas tecnologias. Brasília: Ministério da Educação/Secretaria de Educação Média e Tecnológica; 2002. 244 p.

Brasil. Base Nacional Comum Curricular (texto preliminar). Brasília: Ministério da Educação; 2015. Disponível em: http://basenacionalcomum.mec.gov.br. Acesso em: $29 / 10 / 15$.

Câmara AL. A oração relativa em português sob a perspectiva discursivo-funcional: interface entre a descrição e o ensino. [Tese]. São José do Rio Preto: Universidade Estadual Paulista, Instituto de Biociências, Letras e Ciências Exatas; 2015.

Câmara AL, Pezatti EG. Descrição discursivo-funcional do núcleo nominal da oração relativa em português. Revista do Gel. São Paulo. 2015;12(1):9-32. 
Câmara AL, Abreu-Tardelli LS. O papel da gramática nos livros didáticos de língua portuguesa: um olhar sobre o ensino da oração subordinada adjetiva. Signum. Londrina. 2014;27(2):327-353.

Cereja WR, Magalhães TC. Português: linguagens. 9.a ed. São Paulo: Saraiva; 2013.

Corrêa WR. Oração relativa: o que se fala e o que se aprende no português brasileiro. [Tese]. Campinas: Unicamp, Instituto de Estudos da Linguagem; 1998.

Dik SC. The theory of Funcional Grammar. Part I: The structure of the clause. Dordrecht: Foris; 1989.

Dik SC. The theory of Functional Grammar. Part 1: The structure of the clause. Berlin/ New York: Mouton de Gruyter; 1997. (ed. Kees Hengeveld)

Faraco CE, Moura FM, Maruxo Jr. JH. Língua Portuguesa: linguagem e interação. São Paulo: Ática; 2013.

Hengeveld K, Mackenzie JL. Functional discourse grammar: a typologically-based theory of language structure. Oxford: Oxford University Press; 2008.

Kenedy E. A antinaturalidade pied-piping em orações relativas. [Tese]. Rio de Janeiro: Universidade Federal do Rio de Janeiro; 2007.

Neves MHM. Reflexões sobre o estudo da gramática nas escolas de $1^{\circ}$ e $2^{\circ}$ graus. Alfa São Paulo. 1993;91(37):91-8.

Neves MHM. Gramática na escola. 4.a ed. São Paulo: Contexto; 1999.

Neves MHM. Que gramática estudar na escola? 4.a ed. São Paulo: Contexto; 2011.

Oliveira MR, Cezario MM. PCN à luz do funcionalismo linguístico. Linguagem \& Ensino. Pelotas. 2007;10(1):87-108.

Pezatti EG, Câmara AL. Da descrição ao ensino da oração adjetiva: a perspectiva dos livros didáticos de língua portuguesa. Linguística. São Paulo. 2014;30(2):139-168.

Ramos RA, Takeuki M. Universos Língua Portuguesa. São Paulo: Edições SM; 2012.

Sette MGL, Travalha MA, Barros MRS. Português: linguagens em conexão. São Paulo: Leya; 2013. 
Takahashi F. Ministro quer mais gramática no currículo. Folha de São Paulo. São Paulo. $11 / 10 / 2015$.

Travaglia LC. Gramática ensino plural. 5.a ed. São Paulo: Cortez; 2011.

Travaglia LC. Gramática e interação: uma proposta para o ensino de gramática. 14.a ed. São Paulo: Cortez; 2009.

Recebido em: 31/12/2015

Aceito em: 02/09/2016

Câmara, AL. A oração subordinada adjetiva na produção de sentidos no texto... 